\title{
" Aloe Vera: An Innovative CSR Model for Sustainable Rural Development.
}

\author{
Aniruddha Bodhankar
}

\begin{abstract}
Aloevera is a herb which was neglected till recent times has started gaining popularity in the last decade only. Aloevera herbs are known for its medicinal properties such as skin moisturizer, skin glowing, wrinkles remover and a powerful anti oxidant if taken orally.

As per the amendments in Sec.135 of Indian Companies act 2013 the profit making companies have to spend at least $2 \%$ of their net profit under CSR activity. Companies usually spend this fund through some NGOs in the deprived areas of their own choice for the uplifting the living standard of deprived families.

The author wants to propose an idea of CSR activity through educating or motivating the villagers for cultivating the aloevera plant.

This paper is an outcome of author's close association with few NGOs working in rural developmental areas. This is an empirical paper purely based on secondary published data. This paper tries to examine the possibility of whether aloevera cultivation can form a sustainable CSR activity by the companies. And eventually can become a contract farming activity if the CSR funding is from FMCG or Pharmaceutical Manufacturers.
\end{abstract}

(Key words : Aloe Vera, CSR Activity, Aloevera Value Chain, Sustainability, Contract Farming)

\section{INTRODUCTION}

It is always said that India resides through villages. Although about $60 \%$ of the Indian population belong to rural set up, the employment generation is not sizeable in the rural India. All companies are eyeing for rural markets but none have made any remarkable efforts for sizeable efforts for sustainable employment generation in rural India. But yes of course many companies have made efforts for spending their CSR funds into rural India, but that is inadequate to generated a sustainable livelihood for rural population in India. This research has made an attempt to rediscover the aloe Vera farming from the CSR value chain perspective so as to generate a sustainable employment for rural and deprived population. This research has been conducted recently in July-August 2019 in Vidarbha's Urban, SemiUrban and Rural Markets so as to assess the market feasibility for Aloe Vera farming and whether this can provide the sustainable livelihood for rural population. The sustainability of this CSR activity can be assessed derived by the consumer demand for natural soaps. Soaps enjoy 98\% penetration in the Indian households with per capita consumption of about $442 \mathrm{gm}$ annually ${ }^{2}$. This idea also focuses on Agriculture so as to assess the feasibility of Aloe Vera farming in the areas of Vidarbha and to understand the legal settings involved in it if any.

Content Analysis

Revised Manuscript Received on 14 August, 2019.

Dr. AniruddhaBodhankar, Associate Professor,Dr.Ambedkar Institute of Management Studies \& Research, Nagpur, Maharashtra, India.(Email aniruddha_bodhankar@daimsr.in)
Overview of CSR norms ${ }^{0}$

The Indian companies spent around Rs. 15000 Crore every year on CSR activities. The provision of compulsory spending through Corporate Social Responsibility (CSR) was included in Section 135 of The Indian Companies Act 2013. This spending can be incurred on the following activities as laid down in the said act.

\begin{tabular}{|c|c|}
\hline \multirow{2}{*}{$\begin{array}{l}\text { a. Eradicating Poverty, hunger and } \\
\text { malnutrition. }\end{array}$} & e. Ensuring sustainability \\
\hline & f. Protection of heritage \\
\hline \multirow{2}{*}{ b. Promoting health care \& sanitation. } & \\
\hline & g. Promoting sports \\
\hline \multirow{3}{*}{$\begin{array}{l}\text { c. Provision for vocational skills there by } \\
\text { generating employment opportunities. }\end{array}$} & \\
\hline & h. Contribution towards relief funds \\
\hline & i. working for benefits of countries amed \\
\hline d. Gender equality & forces. \\
\hline
\end{tabular}

As per this act the companies need to set aside a corpus of funds equivalent to $2 \%$ of the total of net profits earned during last three years and spend it on the above CSR activities. The unspent amount on CSR activities need to be deposited in the State Government's Corpus specially created for this purpose within thirty days after the end of financial year.

\section{THE MARKET OF ALOE VERA}

As per the report of IMARC a global market research firm, the present global market for aloe vera gel is of 450 Billion USD and is expected to cross a mark of 950 Billion USD by 2024 . The market is growing at a CAGR of $8.8 \%$ which is almost $6.8 \%$ over and above the population growth rate $^{1}$ Aloe Vera farming is a can be sustainable CSR model. This sustainability may be derived through mainly soap manufacturing industry and pharmaceutical manufacturing industry. These two industries are the major consumers of Aloe Vera Gel.As far as soap industry is concerned, there are over 625 soap manufacturers in India from both organized and unorganized sector. The annual collective revenue generation of Indian Soap manufacturers (and from FMCG manufacturers from soap category) is about 20 Billion USD. The market is growing at a rate of $7 \%$ annually which is about $5 \%$ over and above the incremental population growth. The per capita consumption of soap in India is $442 \mathrm{gm}$ per annum ${ }^{2}$. The $58 \%$ soap consumption is

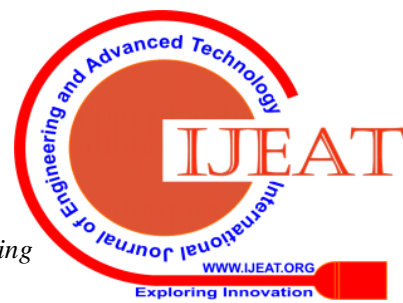


from rural sector. The Indian population is about 130 crore. Out of which about $48 \%$ population is of females which is about 62.40 Crore whereas $52 \%$ population is of males which is about 67.60 Crore. The soap category has a penetration of over $90 \%$ in Indian household. This means that the active market for soap consumption is 117 Crore people in India. Females play a dominating role while buying the soaps. The total soap market in India is estimated to be of about 125000 tones out of which about 20000 tones are received from nationally operative soap brands. ${ }^{1}$ As per the quotes of Mr.SunilKhiani, published in Livemint Dt. 18.07.2019, the personal care segment of FMCG industry with natural ingredients is growing at rate of $14.1 \%$ with a value turnover of Rs. $17500 \mathrm{Cr}^{5}$ Such a huge final consumption market is readily available for natural ingredients including Aloevera. This would be the endeavor of the individual soap manufacturer to establish the utility of Aloevera

\section{ALOE VERA CULTIVATION ZONE}

Aloe Vera (Aloe Barbandensis ${ }^{2}$ ) is a perennial plant in Lilliacae Family. Aloe Vera germinates ideally in humid climate. Such weather conditions are available in interior parts of India. Thus interior India can become the ideal source for growing Aloe Vera Plants. The ideal life span of aloe vera plant is from 5 to 25 years. The aloe plant grows about $8-24$ inches with an average spread of 12 inches to 36 inches. The aloe vera is well known for its medicinal properties involving soothing and healing touch. Aloe Vera Gel acts as an excellent moisturizer and is predominantly used for skin glow. Due to these properties aloe vera has become the first choice of ingredients of soaps for the young India. Aloe Vera plants does not require a huge space to grow. The ideal plantation time for aloe is during spring. Aloe plant has a very high tolerance against drought. All these characteristics make aloe vera cultivation sustainable in India. The corporate houses can invest their CSR funds either in educating the villagers about Aloe Vera Cultivation or buying a large outfield where in the Aloe Vera plants can be grown through the farmers/villagers. The ownership of the land will be with companies while each of the aspirants can be allocated half an hector piece of land for cultivating the Aloe Vera plants. The aspirants will be responsible to cultivation - maintenance - Harvesting - Recultivating the Aloe Vera Plants.

\section{ALOE VERA PROCESSING ZONE}

The aloe vera processing facility can be set up in the same village. The main objective of setting up the Aloe Vera Processing Facility in the same village is to protect Mucopolysaccharide which is the active ingredient of Aloe Vera Gel. The aloe processing involves the following stages. The aloe vera processing facility can again be established by the corporate house as a part of funding under CSR activity. But it will be run by the villagers themselves under supervision of trained personnel. The final output from this processing facility will have the ownership of the individual aspirant or a group of aspirants. The corporate will help them in marketing the output through online platforms.
1. Leaf Processing ${ }^{3}:$ In this process the aloe vera leaves are passed through the pressure rollers to extract the aloe vera jelly. ${ }^{2}$

2. Filleting ${ }^{3}$ : This process involves the separation of the green part (Parenchyma Tissue which contains the active ingredient) from the squeezed material to collect the active ingredient.

3.Homogenization ${ }^{3}$ : This process involves drying, crushing \& grinding of parenchyma tissue at room temperature i.e. about $25^{\circ} \mathrm{C}$ through a high speed grinder.

4 . Filtration ${ }^{3}$ : This is again a mechanical process which involves the removal of debris from the aloe vera jelly so as to prevent its sedimentation on storage thereby protecting its stability.

5.Hot Processing ${ }^{3}$ : This process involves sterilization of this jelly with activated Carbon at $65^{\circ} \mathrm{C}$ for $15-20$ minutes.

6.Cold Processing ${ }^{3}$ : This step involves treatment of the jelly with enzymes like glucose oxidase catlylase so as to inhibit the growth of the diseases and fermentation causing anaerobic bacilli.

7. Storage ${ }^{3}$ : This is the last stage of the processing. The fully processed jelly so captured is stored in amber colour glass bottles so as to protect it from open sunlight.

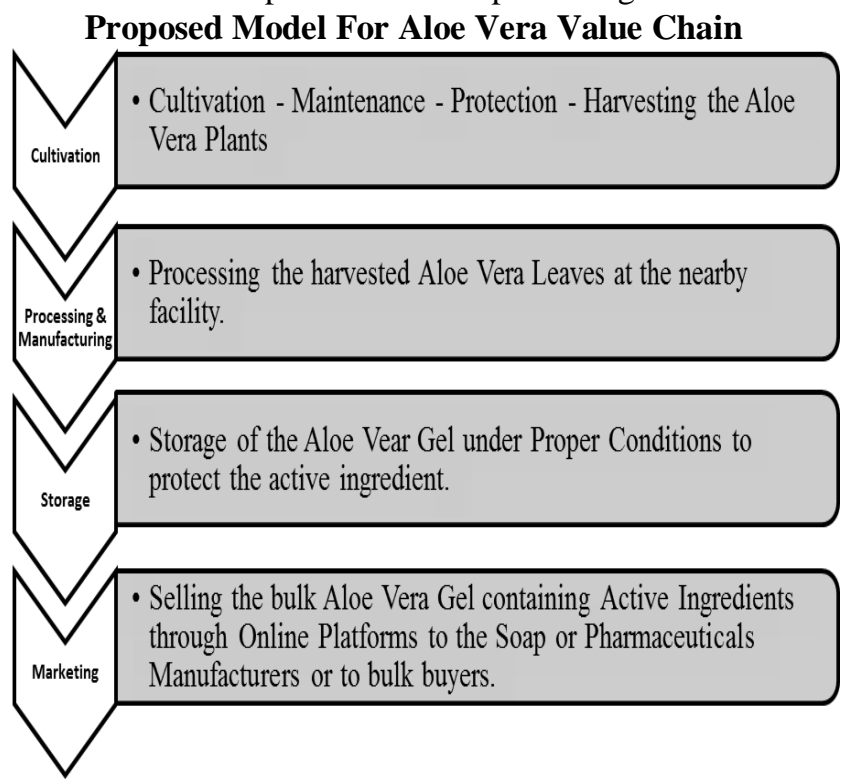

Proposed Value Delivery Model For Aloe Vera

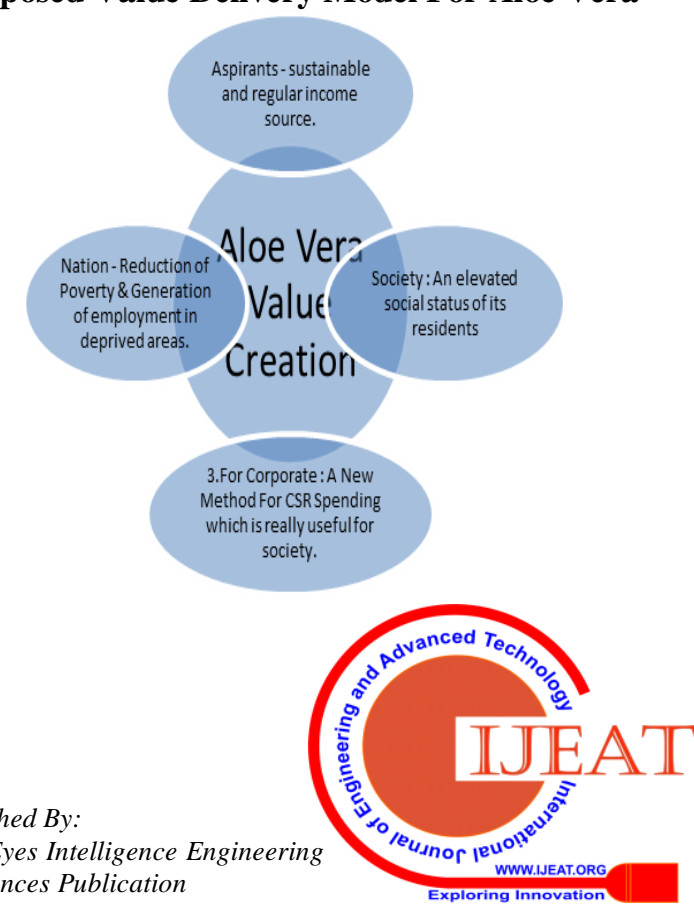


Percentage outlay of CSR Funds On Various Activities

\begin{tabular}{|l|l|l|}
\hline $\begin{array}{l}\text { S. } \\
\text { No. }\end{array}$ & $\begin{array}{l}\text { CSR Spending of Top Companies } \\
\text { Various Heads }\end{array}$ & Towards \\
\hline 1 & Poverty alleviation \& Health Care & $29.40 \%$ \\
\hline 2 & Gender Equality & $3.20 \%$ \\
\hline 3 & Armed Forces & $0.20 \%$ \\
\hline 4 & Various Relief Funds & $1.50 \%$ \\
\hline 5 & Urban Slum Development & $0.60 \%$ \\
\hline 6 & Education \& Skills Development & $32.30 \%$ \\
\hline 7 & Heritage Protection & $1.70 \%$ \\
\hline 8 & Environmental Sustainability & $10.10 \%$ \\
\hline 9 & Rural Sports & $1.90 \%$ \\
\hline 10 & Rural Development & $12.30 \%$ \\
\hline 11 & Others & $6.80 \%$ \\
\hline
\end{tabular}

(Source : CSR Box-Report-2014-2018 ${ }^{6}$ )

The above report indicates that majority of the outlay of CSR funding is for Education \& Skill Development (32.30\%), Poverty Alleviation \& Health care $(29.40 \%)$ and Rural Development (12.30\%). Aloe Vera cultivation can very well be accommodated in theses heads. Eventually this CSR activity can be converted into contract farming if the CSR funding is from FMCG or Pharmaceutical manufacturers. This will certainly help in fulfilling the objectives of CSR funding.

\section{SCOPE FOR FURTHER RESEARCH\& RESULTS}

In this paper the author has tried to put forth a new idea for educating the rural deprived youths for choosingAloevera Farming over their traditional farming as a new innovative CSR initiative by Indian Corporate houses. Under their CSR initiatives the corporate house can impart training from cultivation till marketing of the aloevera gel. Looking into the opportunities available at the market and the growth of natural ingredients market, selling aloevera gel will not be a problem. However a further research is needed in the areas of Companies Act 2013, whether such a type of CSR activity is permitted by this act? Whether imparting skills to rural deprived population and helping them growing their product and marketing it is permitted under the subhead of sustainability? And a detailed analysis of can a new generation of entrepreneurs be developed through such CSR activity? Some research is also required to assess the feasibility of marketing of Aloevera Gel so produced through either formation of Cooperative Societies or even through Contract Farming.

\section{CONCLUSION}

Thus looking into the immense market potential of aloevera has, the companies can think of educating and helping the deprived rural population to undertake aloevera farming, under their CSR activity. Market is ready for acceptance there should be someone who will bridge this gap of production \& Supply. This activity is certainly make the rural population sustainable as with a small one time investment of just Rs.120000/- per hector (through CSR funds) the rural farmers can yield upto rs.230000/- per hector. Such a CSR activity can very well be permitted by the Govt.of India under the heading of sustainability. Rather Govt. should encourage the corporate houses to invest in agriculture sector under CSR activity. Hence in the opinion of the author this CSR model is sustainable and has a potential to be an innovative contract farming model of business.

\section{REFERENCES}

1. 0.URL:https://www.indiafilings.com/learn/csramendments-2019/

2. URL:https://www.imarcgroup.com/aloe-vera-gelmanufacturing-plant

3. URL : https://www.indianmirror.com/indianindustries/soap.html

4. Kulveer Singh Ahlawat,Bhupender Singh Khatkar Processing,Food Applications and safety of Aloe Vera Products: A Review. Journal of Food Science Technology $2011 \quad$ October 48(5):525 533,doi:10.1007/s13197-011-0229-z

5. URL:https://in.kompass.com/a/aloe-veraextracts/2191353/

6. URL:https://www.livemint.com/industry/manufacturing/ opinion-naturals-trend-in-personal-care-is-here-to-stay1563388262499.html

7. URL:https://csrbox.org/media/CSR\%20in_India_Numbe rs_Do_Add_Up_Report-2018_Web-lite.pdf 